\title{
Assessing the Use of Prescription Drugs in Obese Respondents in the National Health and Nutrition Examination Survey
}

\author{
Laura A. Barrett, $\mathrm{MS}^{1}$, Aiwen Xing, $\mathrm{MS}^{2}$, Elizabeth Steidley ${ }^{1}$, Terrence J. Adam, RPh, MD, \\ $\mathrm{PhD}^{3}$, Rui Zhang, $\mathrm{PhD}^{3}$, Zhe He, $\mathrm{PhD}^{1}$ \\ ${ }^{1}$ School of Information, Florida State University, Tallahassee, FL, USA \\ ${ }^{2}$ Department of Statistics, Florida State University, Tallahassee, FL, USA \\ ${ }^{3}$ Institute for Health Informatics and College of Pharmacy, University of Minnesota, \\ Minneapolis, MN, USA
}

\section{Corresponding Author:}

Zhe $\mathrm{He}, \mathrm{PhD}$

School of Information

College of Communication and Information

Florida State University

142 Collegiate Loop

Tallahassee, Florida 32306-2100

zhe@fsu.edu

Phone: 001(850)644-5775

\section{Competing Interests}

None 


\begin{abstract}
Introduction: Obesity is a common disease and a known risk factor for many other conditions such as hypertension, type 2 diabetes, and cancer. Treatment options for obesity include lifestyle changes, pharmacotherapy, and surgical interventions such as bariatric surgery. In this study, we examine the use of prescription drugs and dietary supplements by the individuals with obesity.

Methods: We conducted a cross-sectional analysis of the National Health and Nutrition Examination Survey (NHANES) data 2003-2014. We used multivariate logistic regression to analyze the correlations of demographics and obesity status with the use of prescription drugs and dietary supplement use. We also built machine learning models to predict prescription drug and dietary supplement use using demographic data and obesity status.
\end{abstract}

Results: Individuals with obesity are more likely to take cardiovascular agents $(\mathrm{OR}=1.265,95 \%$ CI 1.222-1.311) and metabolic agents $(\mathrm{OR}=1.398,95 \%$ CI 1.343-1.456) than individuals without obesity. The best performing prediction model for predicting prescription drugs had the accuracy of $74.5 \%$ and the AUROC of 0.817.

Conclusions: This study can inform clinical practice and patient education of the use of prescription drugs and dietary supplements and their correlation with obesity. 
medRxiv preprint doi: https://doi.org/10.1101/2021.11.18.21266536; this version posted November 19, 2021. The copyright holder for this preprint (which was not certified by peer review) is the author/funder, who has granted medRxiv a license to display the preprint in perpetuity.

It is made available under a CC-BY-NC-ND 4.0 International license.

\section{Introduction}

As a major health and economic crisis affecting the modern world, much progress has been made in identifying and developing strategies for preventing and treating obesity. Currently, these treatment options include lifestyle changes, pharmacotherapy, and surgical interventions including intragastric balloons and bariatric surgery. ${ }^{1}$ In terms of pharmacotherapy, there are five approved prescription drugs (RXD) (orlistat, 1999; phentermine/topiramate, 2012; liraglutide, 2014; naltrexone/bupropion, 2014; and semaglutide, 2021) that can be prescribed for weight loss. $^{2}$ All but orlistat, which reduces the absorption of fat, work by helping the individual to limit caloric intake. ${ }^{3}$ There are also four RXD that are similar to amphetamines that can be used shortterm (phendimetrazine, diethylpropion, phentermine, and benzphetamine). ${ }^{4}$ There have been three other well-known RXD that were approved for use and then removed from the market. The first one is fenfluramine/phentermine (fen-phen) which was discontinued in 1997 because fenfluramine was shown to cause cardiac issues. ${ }^{5}$ The second one is sibutramine, which was withdrawn in 2010 due to an increased risk of stroke and myocardial infarction. ${ }^{6}$ The third one is lorcaserin, which was withdrawn in February 2020 after a clinical trial showed an increased occurrence of cancers. ${ }^{7}$ Due to the cost of pharmacotherapy and surgical interventions, as well as other reasons, dietary supplements (DS) are often used as a cost-sensitive and easily accessible, albeit less scientifically supported, alternative treatment of obesity. ${ }^{8,9}$

Individuals with obesity face an increased risk of chronic diseases, namely depression, type 2 diabetes, cardiovascular disease, and many cancers including those of the colon, breast, kidney, and pancreas. ${ }^{10}$ Thus, individuals with obesity often must use RXDs to manage these conditions. Overall, RXD use in the United States has increased. ${ }^{9}$ This is partly influenced by the development of new RXDs, the expansion of RXD coverage by insurance companies, and 
increased RXD marketing by pharmaceutical companies. ${ }^{9}$ The greatest increase in RXD use has been in those used for treating conditions found to be associated with obesity, specifically antihypertensives, antihyperlipidemic, antidiabetics, and antidepressants. ${ }^{11}$

Recent studies have researched obesity in relation to various specific drugs or drug types. ${ }^{12-16}$ There have also been recent studies that looked at various aspects of obesity such as childhood obesity, ${ }^{16,17}$ obesity and hours spent at work, ${ }^{18}$ exposure to certain pollutants or chemicals, ${ }^{19-21}$ trends in obesity, ${ }^{22}$ and obesity and waist circumference. ${ }^{23}$ However, there have not been any studies that look at overall RXD use in individuals with obesity. Being able to see this bird's eye view of this relationship is important because understanding the patterns of RXD use among people with obesity, who often have other chronic conditions, can inform both clinical practice and research. ${ }^{9}$ This is challenging because there are cross-over issues between RXD, their side effect of weight gain, and their therapeutic effect on obesity and its comorbidities. For example, certain blood-glucose-lowering RXD and psychotropics may lead to unintended weight gain. ${ }^{24}$ In this project, we aim to gain an in-depth understanding of both the relationship between obesity and RXD use, as well as the correlations between specific RXD and DS use in individuals with obesity. We also aim to understand if demographic variables and obesity status can predict an individual's likelihood of using any RXD or DS, not just specific RXD or DS.

\section{Materials and Methods}

The National Center for Health Statistics of CDC has been conducting the National Health and Nutrition Examination Survey (NHANES) as a continuous cross-sectional health survey. ${ }^{25}$ It samples the non-institutionalized population of the United States with a stratified multistage probability model and releases results of a set of health surveys, medical examinations, a 
medRxiv preprint doi: https://doi.org/10.1101/2021.11.18.21266536; this version posted November 19, 2021. The copyright holder for this preprint (which was not certified by peer review) is the author/funder, who has granted medRxiv a license to display the preprint in perpetuity.

It is made available under a CC-BY-NC-ND 4.0 International license .

physical, and laboratory test every two years. Its rigorous quality control ensures high-quality data collection and national representativeness. The NHANES data have been used in many public health and epidemiology studies. ${ }^{\mathbf{2 6}}$

Demographic, physical examination, prescription drug (RXD) and dietary supplement (DS) use, and health insurance information were extracted from NHANES for survey years 2003 - 2014 (6 survey cycles). The 12-year sample weight (the number of people in the US population that a sample in the combined sample can represent) was calculated according to the analytical guideline of NHANES. ${ }^{25}$ The obese group is defined as: (1) BMI $\geq 30 \mathrm{~kg} / \mathrm{m}^{2}$, (2) age $\geq 18$, and (3) reported RXD use. From the original NHANES data, 1937 respondents with no BMI and 32 respondents with no RXD use information were removed from the dataset.

\section{Data Analysis}

Basic Characteristics: A profile for each group was created that included sex, age, race, annual household income, and health insurance status.

Statistical Analysis: We conducted multivariate logistic regression analyses to access: 1) the associations between using RXD/DS and variables of interests (i.e., demographic characteristics and obesity status) and 2) the associations between taking specific types of RXD and obesity status. Weighted multivariate logistic regression analyses were used to obtain odds ratios (OR) and 95\% CIs with 12-year sample weight. All interested variables were introduced in the model first then backward elimination with a threshold of $\mathrm{p}=0.05$ was applied to eliminate variables. We kept only the variables that were significant in the initial model in the final model. The significance level was set as 0.05. All statistical analyses were performed by SAS software (SAS Institute Inc), version 9.4. 
medRxiv preprint doi: https://doi.org/10.1101/2021.11.18.21266536; this version posted November 19, 2021. The copyright holder for this preprint (which was not certified by peer review) is the author/funder, who has granted medRxiv a license to display the preprint in perpetuity.

It is made available under a CC-BY-NC-ND 4.0 International license .

We performed two separate logistic regression analyses. 1) Usage based on the specific number of RXD/DS that the individual used was the dependent variable. Demographic characteristics were included as independent variables to examine whether taking a specific number of RXD/DS was significantly associated with demographic characteristics within nonobese or obese group separately. This regression evaluated covariates down to the two groups. 2) Obesity status and demographic characteristics were included as independent variables to test their associations with taking a specific number of RXD/DS within the whole population. In the second analysis, the dichotomous dependent variable was whether taking the specific types of RXD; obesity status was set as independent variable with reference as non-obese group.

Predictive Modeling: We used Weka ${ }^{27}$ to evaluate different machine learning models for predicting whether a respondent used one or more RXD or DS, respectively. In the first round of the predictive modelling, the predictors included age group, sex, BMI category, race, annual household income, and insurance status. As we are also interested in seeing whether DS use would help predict RDX use and vice versa, in the second round of predictive modeling, DS use or RXD use was added as a predictor for predicting the use of the other type. We used feature selection based on correlation ("CorrelationAttributeEval" in Weka) to rank the importance of the predictors. We evaluated four major machine learning algorithms including Naïve Bayes, Logistic Regression, SMO (Weka's implementation of Support Vector Machine), and Random Forest. Deep learning techniques were not employed because of the small number of predictors in this dataset. The data was preprocessed to make all numerical data nominal. 10-fold cross validation was employed. In each fold, $90 \%$ of the data was used for training and $10 \%$ of the data was used for testing. The models were compared using overall accuracy, precision, recall, F1score, and AUROC. 
medRxiv preprint doi: https://doi.org/10.1101/2021.11.18.21266536; this version posted November 19, 2021. The copyright holder for this preprint (which was not certified by peer review) is the author/funder, who has granted medRxiv a license to display the preprint in perpetuity.

It is made available under a CC-BY-NC-ND 4.0 International license .

\section{Results}

\section{Basic Characteristics}

Table 1 shows the basic characteristics of the two groups in regard to their RXD use. There are a few differences based on obesity status and demographics. The non-obese group includes $52.64 \%$ that report taking 1 or more RXD. The obese group has a higher reported use at $63.68 \%$. In both groups, females report higher use than males. In addition, RXD use increases with age in both groups. Race also plays a role in reported RXD use in both groups; Non-Hispanic Whites have the highest percentages of use while Mexican Americans show the lowest percentages. Lastly, in both groups, those with health insurance reported higher RXD use than those that reported not having insurance.

Table 1. Basic characteristics of the study population

\begin{tabular}{|c|c|c|c|c|c|c|c|c|}
\hline & \multicolumn{4}{|c|}{ Non-obese } & \multicolumn{4}{|c|}{ Obese } \\
\hline & \multicolumn{2}{|c|}{0 RXD } & \multicolumn{2}{|c|}{1 or more RXD } & \multicolumn{2}{|c|}{ O RXD } & \multicolumn{2}{|c|}{1 or more RXD } \\
\hline Variable & Weight & $\%$ & Weight & $\%$ & Weight & $\%$ & Weight & $\%$ \\
\hline Total & 66508809 & $47.36 \%$ & 73921759 & $52.64 \%$ & 26760055 & $36.32 \%$ & 46917732 & $63.68 \%$ \\
\hline \multicolumn{9}{|l|}{ Gender } \\
\hline Male & 38107616 & $54.91 \%$ & 31295757 & $45.09 \%$ & 14353846 & $42.29 \%$ & 19590434 & $57.71 \%$ \\
\hline Female & 28401193 & $39.99 \%$ & 42626002 & $60.01 \%$ & 12406209 & $31.22 \%$ & 27327297 & $68.78 \%$ \\
\hline \multicolumn{9}{|l|}{ Age } \\
\hline $18-24$ & 14836894 & $70.18 \%$ & 6304274 & $29.82 \%$ & 4660202 & $71.00 \%$ & 1903380 & $29.00 \%$ \\
\hline $25-34$ & 16942291 & $65.69 \%$ & 8849137 & $34.31 \%$ & 7470412 & $63.24 \%$ & 4343207 & $36.76 \%$ \\
\hline $35-44$ & 14731496 & $58.57 \%$ & 10418677 & $41.43 \%$ & 6813783 & $45.62 \%$ & 8121188 & $54.38 \%$ \\
\hline $45-54$ & 11677424 & $44.68 \%$ & 14456138 & $55.32 \%$ & 4735950 & $30.01 \%$ & 11047591 & $69.99 \%$ \\
\hline $55-64$ & 5554943 & $29.58 \%$ & 13224166 & $70.42 \%$ & 2308369 & $18.04 \%$ & 10485145 & $81.96 \%$ \\
\hline $65-74$ & 1818148 & $14.32 \%$ & 10874221 & $85.68 \%$ & 570357 & $7.32 \%$ & 7222091 & $92.68 \%$ \\
\hline 75 and over & 947610 & $8.82 \%$ & 9795144 & $91.18 \%$ & 200980 & $5.03 \%$ & 3795126 & $94.97 \%$ \\
\hline \multicolumn{9}{|l|}{ Race } \\
\hline Mexican American & 7904327 & $72.27 \%$ & 3033546 & $27.73 \%$ & 4381332 & $61.83 \%$ & 2704766 & $38.17 \%$ \\
\hline Other Hispanic & 4330888 & $63.44 \%$ & 2496048 & $36.56 \%$ & 2023727 & $55.70 \%$ & 1609763 & $44.30 \%$ \\
\hline $\begin{array}{l}\text { Non-Hispanic } \\
\text { White }\end{array}$ & 39765947 & $40.57 \%$ & 58255518 & $59.43 \%$ & 14217576 & $29.17 \%$ & 34528101 & $70.83 \%$ \\
\hline $\begin{array}{l}\text { Non-Hispanic } \\
\text { Black }\end{array}$ & 7805243 & $58.33 \%$ & 5575636 & $41.67 \%$ & 4851478 & $42.92 \%$ & 6452578 & $57.08 \%$ \\
\hline $\begin{array}{l}\text { Other Race or } \\
\text { Multi-Racial }\end{array}$ & 6702401 & $59.51 \%$ & 4561010 & $40.49 \%$ & 1285941 & $44.21 \%$ & 1622523 & $55.79 \%$ \\
\hline \multicolumn{9}{|l|}{$\begin{array}{l}\text { Household } \\
\text { Income }\end{array}$} \\
\hline$\$ 0$ to $\$ 34,999$ & 20270690 & $48.07 \%$ & 21898357 & $51.93 \%$ & 8968445 & $36.82 \%$ & 15386882 & $63.18 \%$ \\
\hline
\end{tabular}


medRxiv preprint doi: https://doi.org/10.1101/2021.11.18.21266536; this version posted November 19, 2021. The copyright holder for this preprint (which was not certified by peer review) is the author/funder, who has granted medRxiv a license to display the preprint in perpetuity.

It is made available under a CC-BY-NC-ND 4.0 International license .

\begin{tabular}{|c|c|c|c|c|c|c|c|c|}
\hline$\$ 35,000$ to $\$ 74,999$ & 19710293 & $47.96 \%$ & 21385868 & $52.04 \%$ & 9041692 & $37.40 \%$ & 15136891 & $62.60 \%$ \\
\hline$\$ 75,000$ and over & 21041758 & $44.89 \%$ & 25829035 & $55.11 \%$ & 6765778 & $33.33 \%$ & 13530986 & $66.67 \%$ \\
\hline \multicolumn{9}{|l|}{$\begin{array}{l}\text { Health } \\
\text { Insurance* }\end{array}$} \\
\hline Yes & 45836430 & $40.83 \%$ & 66422640 & $59.17 \%$ & 17826007 & $29.68 \%$ & 42227916 & $70.32 \%$ \\
\hline No & 20600914 & $73.47 \%$ & 7439920 & $26.53 \%$ & 8918505 & $65.61 \%$ & 4675065 & $34.39 \%$ \\
\hline
\end{tabular}

*Overall insurance coverage was $80.5 \%$ covered and $19.5 \%$ not covered.

\section{Specific RXD Types}

For the identified RXD types, we evaluated the association between the specific types of RXD use and obesity status. Table 2 shows the odds ratio between obese and non-obese group taking prescription drugs. While looking at the types of RXD, there were differences in use between the obese and non-obese groups. Cardiovascular agents are the most used RXD type in both groups. This is not surprising given the prevalence of cardiovascular diseases in the United States. Compared with those in the non-obese group, individuals with obesity are more likely to take cardiovascular agents $(\mathrm{OR}=1.265,95 \%$ CI $1.222-1.311)$ and metabolic agents $(\mathrm{OR}=1.398,95 \%$ CI 1.343-1.456). Figure 1 shows a comparison of the cardiovascular agents and the metabolic agents based on percent of the RXD used by each age group. In both types of RXD, the obese population uses more of the RXD in the younger age groups, starting clearly at 25-34. The decrease in usage by obese individuals in the 75+ group may, in part, reflect the potential mixed effects of obesity in old age, where those with a high BMI have a lower mortality, though only among this older group. ${ }^{28}$ 
medRxiv preprint doi: https://doi.org/10.1101/2021.11.18.21266536; this version posted November 19, 2021. The copyright holder for this preprint (which was not certified by peer review) is the author/funder, who has granted medRxiv a license to display the preprint in perpetuity.

It is made available under a CC-BY-NC-ND 4.0 International license .

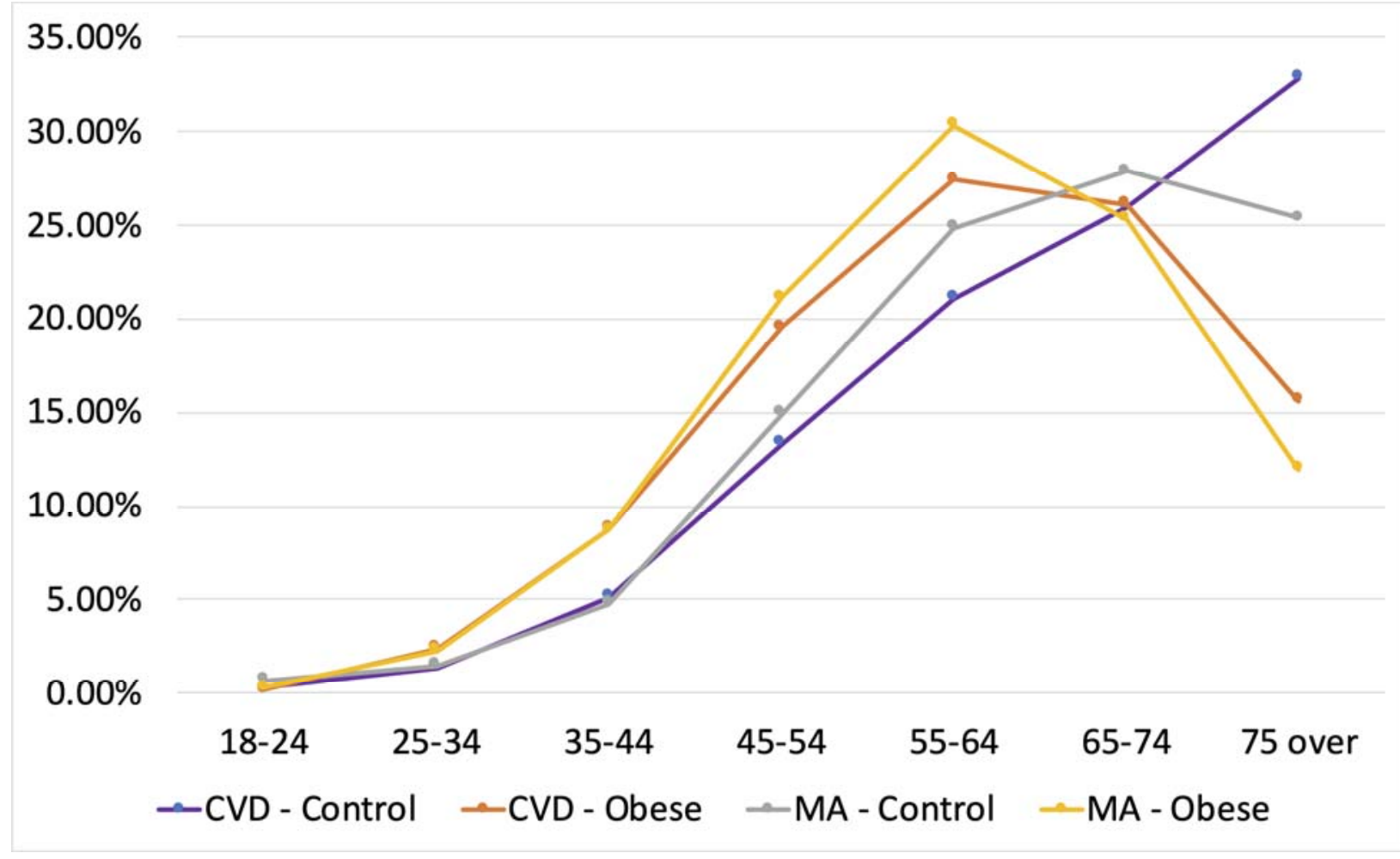

Figure 1. Comparison of percent of the RXD used by age group. CVD is cardiovascular drug. MA is metabolic agent.

Table 2. Odds ratios between obese and non-obese group taking prescription drugs

\begin{tabular}{|c|c|c|c|c|c|c|}
\hline Prescription drugs & $\begin{array}{l}\text { Obese } \\
(\%)\end{array}$ & $\begin{array}{l}\text { Non-Obese } \\
(\%)\end{array}$ & Odds ratios & \multicolumn{2}{|c|}{ 95\% Wald CL } & Pr $>$ ChiSq \\
\hline Cardiovascular agents & 29.49 & 26.77 & 1.265 & 1.222 & 1.311 & $<.0001$ \\
\hline Metabolic agents & 20.83 & 17.32 & 1.398 & 1.343 & 1.456 & $<.0001$ \\
\hline Central nervous system agents & 15.53 & 15.85 & 0.884 & 0.848 & 0.921 & $<.0001$ \\
\hline Gastrointestinal agents & 5.95 & 6.81 & 0.894 & 0.84 & 0.951 & 0.0004 \\
\hline Respiratory agent & 5.87 & 6.10 & 0.933 & 0.877 & 0.993 & 0.0288 \\
\hline Psychotherapeutic agents & 5.77 & 5.94 & 0.936 & 0.883 & 0.993 & 0.0276 \\
\hline Hormones/hormone modifiers & 5.42 & 7.84 & 0.617 & 0.583 & 0.654 & $<.0001$ \\
\hline Topical agents & 2.66 & 3.62 & 0.749 & 0.688 & 0.814 & $<.0001$ \\
\hline Anti-infectives & 2.37 & 3.56 & 0.637 & 0.584 & 0.696 & $<.0001$ \\
\hline Coagulation modifiers & 1.96 & 2.22 & 0.972 & 0.865 & 1.092 & 0.6297 \\
\hline Antineoplastics & 0.64 & 0.87 & 0.763 & 0.642 & 0.907 & 0.0022 \\
\hline
\end{tabular}

Correlation Analysis of RDX and DS Use with Demographic Characteristics 
medRxiv preprint doi: https://doi.org/10.1101/2021.11.18.21266536; this version posted November 19, 2021. The copyright holder for this preprint (which was not certified by peer review) is the author/funder, who has granted medRxiv a license to display the preprint in perpetuity.

It is made available under a CC-BY-NC-ND 4.0 International license .

Examining the correlation between reported RDX use and demographic characteristics for the non-obese and obese groups, we found a few items of interest. Male from both the non-obese and the obese group were significantly less likely than female to use RXD $\left(O R_{\text {control }}=0.537,95 \%\right.$ CI $0.504-0.573$, OR $_{\text {obese }}=0.571,95 \%$ CI 0.521-0.626). Compared with those individuals with obesity older than 75 , adults younger than 54 were significantly less likely to use RXD. When controlling for all other variables, people covered by insurance were around 1.5 times $(\mathrm{p}<.0001$ for non-obese group and $\mathrm{p}=0.0056$ for obese group) as likely to use RXD than those who did not have any insurance coverage. Specifically, individuals with obesity covered by Medicare were 3.741 times more likely to use RXD ( $\mathrm{p}<.0001)$ than those with no Medicare covered.

When looking at the correlation between reported DS use and demographic characteristics for the non-obese and obese groups, we found a few interesting findings. Within the obese group, Mexican American, other Hispanic, and Non-Hispanic Black were significantly less likely to take DS compared with Non-Hispanic White. A significant correlation was found between Annual Household Income and DS use for both groups, people with higher income being more likely to take DS. Individuals with obesity covered by private insurance, Medicare, and other government insurance were significantly more likely to take DS, while individuals without obesity covered by insurance were 1.363 times as likely to take DS than those who were not covered by any insurance while holding other variables constant.

We were also interested in how obesity status and demographic characteristics associated with the use RXD or that of DS within the whole population group (Table 3). Female and older people were more likely to take RXD or DS. Annual Household Income is an interesting factor, as people with higher income were significantly more likely to take DS. For RXD use, only those with a household income between $\$ 45000$ to $\$ 54999$ and $\$ 65000$ to $\$ 74999$ were found to be 
medRxiv preprint doi: https://doi.org/10.1101/2021.11.18.21266536; this version posted November 19, 2021. The copyright holder for this preprint (which was not certified by peer review) is the author/funder, who has granted medRxiv a license to display the preprint in perpetuity.

It is made available under a CC-BY-NC-ND 4.0 International license .

statistically significant. In addition, people covered by Medicaid were around two times as likely to take RXD but less likely to take DS (OR=0.852, $\mathrm{P}<0.0236)$. This may be due to the limited financial means to buy DS in this population. Individuals with obesity were more likely to take $\mathrm{RXD}(\mathrm{OR}=1.558,95 \%$ CI 1.473-1.647) while less likely to take DS (OR=0.766, 95\% CI 0.7280.806) compared with individuals without obesity.

Table 3. Reported prescription drug use/dietary supplements use by demographic characteristics and obesity status correlates.

\begin{tabular}{|c|c|c|c|c|c|c|c|c|}
\hline \multirow[t]{2}{*}{ Variable } & \multicolumn{4}{|c|}{ RXD use } & \multicolumn{4}{|c|}{ DS use } \\
\hline & Odds ratio & \multicolumn{2}{|c|}{$\begin{array}{l}\text { 95\% Wald } \\
\text { CL }\end{array}$} & $\begin{array}{l}\mathrm{P} \\
\text { value }\end{array}$ & $\begin{array}{l}\text { Odds } \\
\text { ratio }\end{array}$ & \multicolumn{2}{|c|}{$\begin{array}{l}95 \% \text { Wald } \\
\text { CL }\end{array}$} & $\begin{array}{l}\mathrm{P} \\
\text { value }\end{array}$ \\
\hline \multicolumn{9}{|l|}{ Gender } \\
\hline Male & 0.551 & 0.523 & 0.58 & $<.0001$ & 0.566 & 0.54 & 0.594 & $<.0001$ \\
\hline Female (reference) & 1 & & & & 1 & & & \\
\hline \multicolumn{9}{|l|}{ Age Group } \\
\hline $18-24$ & 0.107 & 0.086 & 0.134 & $<.0001$ & 0.25 & 0.213 & 0.294 & $<.0001$ \\
\hline $25-34$ & 0.136 & 0.11 & 0.169 & $<.0001$ & 0.346 & 0.296 & 0.405 & $<.0001$ \\
\hline $35-44$ & 0.201 & 0.163 & 0.249 & $<.0001$ & 0.391 & 0.335 & 0.457 & $<.0001$ \\
\hline $45-54$ & 0.349 & 0.282 & 0.431 & $<.0001$ & 0.539 & 0.462 & 0.627 & $<.0001$ \\
\hline $55-64$ & 0.627 & 0.506 & 0.777 & $<.0001$ & 0.827 & 0.71 & 0.964 & 0.0148 \\
\hline $65-74$ & 0.727 & 0.594 & 0.888 & 0.0018 & 0.881 & 0.775 & 1.001 & 0.0521 \\
\hline 75 over (reference) & 1 & & & & 1 & & & \\
\hline \multicolumn{9}{|l|}{ Race } \\
\hline Mexican American & 0.454 & 0.41 & 0.503 & $<.0001$ & 0.582 & 0.529 & 0.64 & $<.0001$ \\
\hline Other Hispanic & 0.502 & 0.444 & 0.569 & $<.0001$ & 0.745 & 0.664 & 0.836 & $<.0001$ \\
\hline Non-Hispanic White (reference) & 1 & & & & 1 & & & \\
\hline Non-Hispanic Black & 0.589 & 0.541 & 0.64 & $<.0001$ & 0.59 & 0.545 & 0.639 & $<.0001$ \\
\hline $\begin{array}{l}\text { Other Race - Including Multi- } \\
\text { Racial }\end{array}$ & 0.548 & 0.494 & 0.608 & $<.0001$ & 0.902 & 0.818 & 0.994 & 0.0365 \\
\hline \multicolumn{9}{|l|}{ Annual Household Income } \\
\hline$\$ 0$ to $\$ 4,999$ & 0.977 & 0.792 & 1.206 & 0.8301 & 0.636 & 0.521 & 0.777 & $<.0001$ \\
\hline$\$ 5,000$ to $\$ 9,999$ & 1.116 & 0.94 & 1.324 & 0.21 & 0.556 & 0.476 & 0.649 & $<.0001$ \\
\hline$\$ 10,000$ to $\$ 14,999$ & 1.033 & 0.905 & 1.18 & 0.6272 & 0.557 & 0.495 & 0.628 & $<.0001$ \\
\hline$\$ 15,000$ to $\$ 19,999$ & 0.921 & 0.807 & 1.051 & 0.2206 & 0.556 & 0.494 & 0.626 & $<.0001$ \\
\hline$\$ 20,000$ to $\$ 24,999$ & 1.014 & 0.9 & 1.142 & 0.8248 & 0.628 & 0.564 & 0.699 & $<.0001$ \\
\hline$\$ 25,000$ to $\$ 34,999$ & 0.917 & 0.834 & 1.01 & 0.0781 & 0.644 & 0.59 & 0.703 & $<.0001$ \\
\hline$\$ 35,000$ to $\$ 44,999$ & 0.95 & 0.862 & 1.046 & 0.296 & 0.774 & 0.708 & 0.845 & $<.0001$ \\
\hline$\$ 45,000$ to $\$ 54,999$ & 0.887 & 0.805 & 0.977 & 0.0149 & 0.789 & 0.722 & 0.863 & $<.0001$ \\
\hline$\$ 55,000$ to $\$ 64,999$ & 0.913 & 0.822 & 1.013 & 0.0859 & 0.772 & 0.701 & 0.851 & $<.0001$ \\
\hline$\$ 65,000$ to $\$ 74,999$ & 0.871 & 0.781 & 0.97 & 0.0122 & 0.83 & 0.75 & 0.918 & 0.0003 \\
\hline$\$ 75,000$ and over (reference) & 1 & & & & 1 & & & \\
\hline \multicolumn{9}{|l|}{ Covered by any insurance } \\
\hline Yes & 1.57 & 1.332 & 1.85 & $<.0001$ & 1.215 & 1.071 & 1.377 & 0.0024 \\
\hline No (reference) & 1 & & & & 1 & & & \\
\hline \multicolumn{9}{|l|}{ Covered by private insurance } \\
\hline Yes & 1.4 & 1.202 & 1.629 & $<.0001$ & 1.274 & 1.141 & 1.423 & $<.0001$ \\
\hline No (reference) & 1 & & & & 1 & & & \\
\hline
\end{tabular}


medRxiv preprint doi: https://doi.org/10.1101/2021.11.18.21266536; this version posted November 19, 2021. The copyright holder for this preprint (which was not certified by peer review) is the author/funder, who has granted medRxiv a license to display the preprint in perpetuity.

It is made available under a CC-BY-NC-ND 4.0 International license .

\begin{tabular}{|c|c|c|c|c|c|c|c|c|}
\hline \multicolumn{9}{|c|}{ Covered by Medicare } \\
\hline Yes & 2.811 & 2.371 & 3.332 & $<.0001$ & 1.348 & 1.186 & 1.532 & $<.0001$ \\
\hline No (reference) & 1 & & & & 1 & & & \\
\hline \multicolumn{9}{|c|}{ Covered by Medicaid } \\
\hline Yes & 1.995 & 1.671 & 2.382 & $<.0001$ & 0.852 & 0.742 & 0.979 & 0.0236 \\
\hline No (reference) & 1 & & & & 1 & & & \\
\hline \multicolumn{9}{|c|}{ Covered by other government insurance } \\
\hline Yes & 1.92 & 1.627 & 2.267 & $<.0001$ & 1.181 & 1.041 & 1.34 & 0.0097 \\
\hline No (reference) & 1 & & & & 1 & & & \\
\hline \multicolumn{9}{|l|}{ Obesity } \\
\hline Yes & 1.558 & 1.473 & 1.647 & $<.0001$ & 0.766 & 0.728 & 0.806 & $<.0001$ \\
\hline No (reference) & 1 & & & & 1 & & & \\
\hline
\end{tabular}

Figure 2 shows the correlation between age, BMI, and the number of RDX and DS used by both the obese group and non-obese group. Figure 2(a) illustrates the correlation between the average number of RXD used by a respondent and the age groups. Generally, the average number of RXD used by a respondent increased with an increase in age for both non-obese and obese groups. Regardless of age, individuals with obesity generally take more RXD than individuals without obesity. The distribution of the average number of RXD used shows a positive skewness distribution: the average number is greater than the median within each age group. Figure 2(b) illustrates the correlation between the average number of DS used and the age groups. Similarly, the average number of DS used generally increased with an increase in age for both groups, with people aging from 65 to 74 taking the highest number of DS (mean of nonobese vs. obese: 2.28 vs.1.86). However, the difference in average number of DS used between the obese and non-obese groups was not as clear as that between the number of RXD used and age group. Figure 1(c) illustrates the correlation between the number of RXD/DS used and BMI. BMI mainly clustered around 18 to $37 \mathrm{~kg} / \mathrm{m}^{2}$. People typically take higher numbers of RXD than DS. The largest maximum number of DS used (24) can be found among people with BMI from 18 to $22 \mathrm{~kg} / \mathrm{m}^{2}$, the healthiest group, compared with other BMI groups. The highest average 
medRxiv preprint doi: https://doi.org/10.1101/2021.11.18.21266536; this version posted November 19, 2021. The copyright holder for this preprint (which was not certified by peer review) is the author/funder, who has granted medRxiv a license to display the preprint in perpetuity. It is made available under a CC-BY-NC-ND 4.0 International license .

number of RXD used can be found among people with BMI from 63 to $67 \mathrm{~kg} / \mathrm{m}^{2}$. As both of the BMI categories from 83 to $87 \mathrm{~kg} / \mathrm{m}^{2}$ and from 128 to $132 \mathrm{~kg} / \mathrm{m}^{2}$ have only one person included in the sample, no bar shows in the figure, the points indicate the true value among those groups. 
medRxiv preprint doi: https://doi.org/10.1101/2021.11.18.21266536; this version posted November 19, 2021. The copyright holder for this preprint (which was not certified by peer review) is the author/funder, who has granted medRxiv a license to display the preprint in perpetuity.

It is made available under a CC-BY-NC-ND 4.0 International license .

(a)

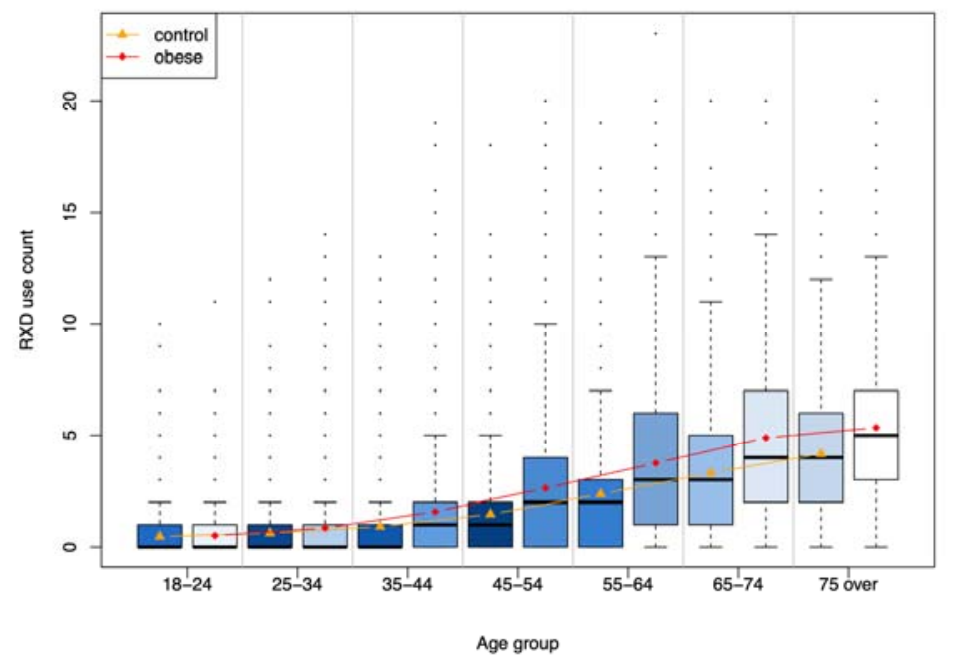

(b)
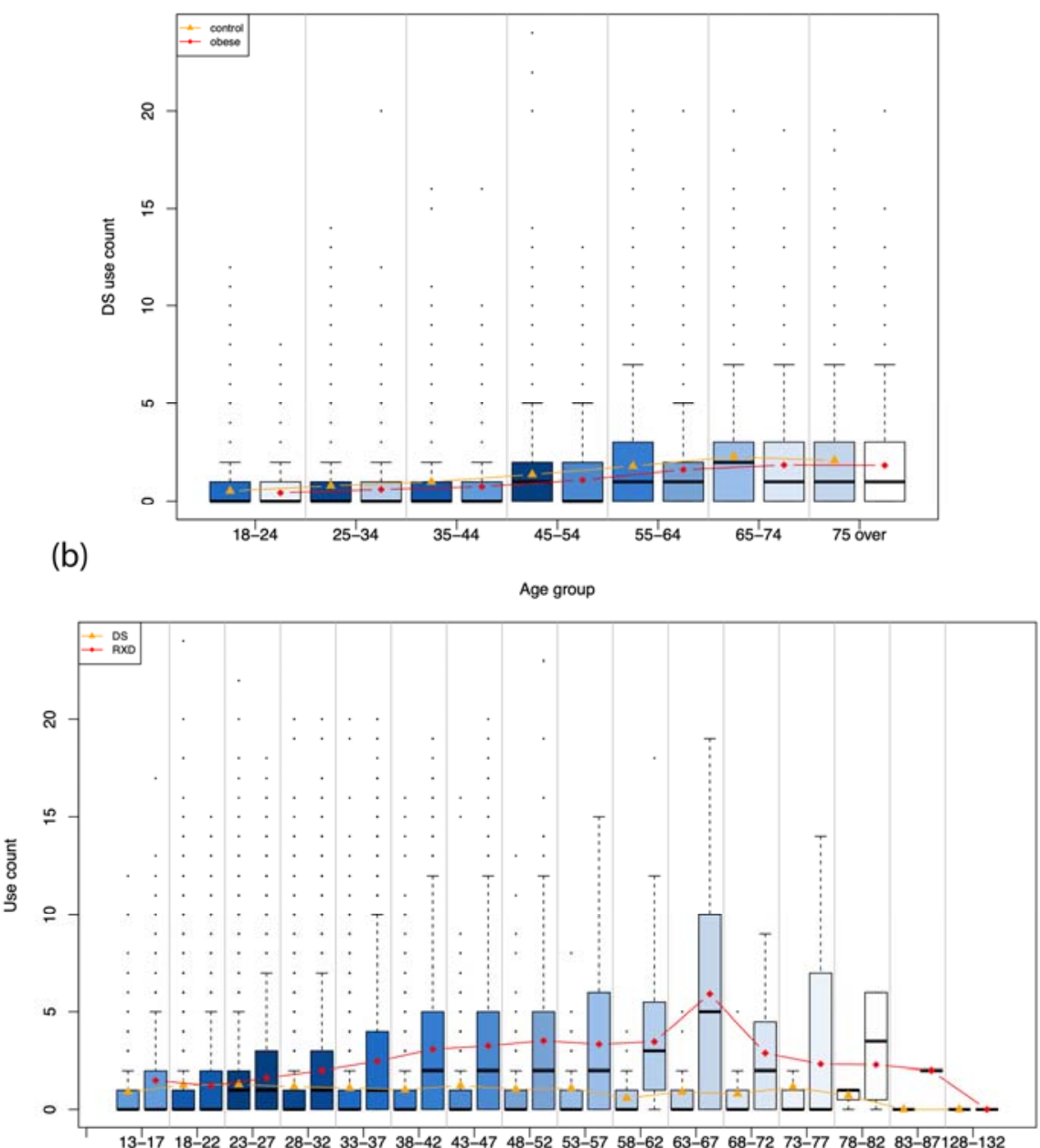

(c)

BMI

Figure 2. (a) The correlation between the number of RXD used and age; (b) The correlation between the number of DS used and age; (c) the number of RXD/DS used compared to BMI. The shade of color represents the aggregated weights within each age group. The points of line indicate the average number used within each age group. The shade of the color represents the 
medRxiv preprint doi: https://doi.org/10.1101/2021.11.18.21266536; this version posted November 19, 2021. The copyright holder for this preprint (which was not certified by peer review) is the author/funder, who has granted medRxiv a license to display the preprint in perpetuity.

It is made available under a CC-BY-NC-ND 4.0 International license .

aggregated weights within each age group. The points on the line indicate the average number used within each age group.

\section{Prediction of RDX Use and DS Use Using Machine Learning}

Table S1 and S2 in the Supplementary Material show the detailed results of predicting DS and RXD use. Prediction of DS use (binary variable) was not as accurate as prediction of RXD use (binary variable). Results from the models run were similar for DS use with the highest overall accuracy being $64.61 \%$ and the AUROC at 0.7 . The results for RXD use were better, with the highest overall accuracy being $74.5 \%$ and the highest AUROC at 0.817 . To see if results would change with the addition of the variable DS use (for RXD use prediction) and RXD use (for DS prediction) the same machine learning algorithms were evaluated again. The overall accuracy and AUROC increased slightly in the DS models. For the RXD models, the accuracy decreased slightly while the AUROC increased slightly. This shows that adding the extra predictor did not make a significant contribution to the predictions. For DS prediction, RXD use, insurance status, and sex were the top three important features. For RXD prediction, insurance status, DS use, and age were the top three important features. In both cases, BMI category and annual household income were the least two important features.

\section{Discussion}

Individuals with obesity face an increased risk of chronic diseases, namely depression, type 2 diabetes, cardiovascular disease, and many cancers including those of the colon, breast, kidney, and pancreas. ${ }^{10}$ Individuals often must use RXD to manage these conditions. Overall, RXD use in the United States has increased. ${ }^{9}$ This is partly influenced by the development of new RXD, the expansion of RXD coverage by insurance companies, and increased RXD marketing by pharmaceutical companies. The greatest increase in RXD use has been in those used for treating 
medRxiv preprint doi: https://doi.org/10.1101/2021.11.18.21266536; this version posted November 19, 2021. The copyright holder for this preprint (which was not certified by peer review) is the author/funder, who has granted medRxiv a license to display the preprint in perpetuity.

It is made available under a CC-BY-NC-ND 4.0 International license .

conditions found to be associated with obesity, specifically antihypertensives, antihyperlipidemic, antidiabetics, and antidepressants. ${ }^{11}$

In this study, we used NHANES data from 2003-2014 to examine RXD and DS use in relation to obesity status. We showed that demographics and obesity status do play a role in usage. These findings are not unexpected as there are a number of comorbidities with obesity that require RXD. The difference in usage based on sex is explainable because females tend to have more consistent visits to medical practitioners and typically use more RXD. ${ }^{29}$ The increase in RDX use shown with age, can be explained by the increased prevalence in clinical comorbidities as the population gets older and is consistent with prior population studies. ${ }^{30}$ The differences in race can be explained by the healthcare and insurance gap seen in minority races. ${ }^{31}$ The increased use by those that are insured can be explained by an increased use of health care services and the associated increase coverage of RXD. ${ }^{32}$ Regarding specific RXD types, cardiovascular agents and metabolic agents were used more by the obese group than the nonobese group. This is due to the comorbidities commonly co-occurring with obesity that are major risk factors for cardiovascular diseases. Another finding was the hormone/hormone modifiers and psychotherapeutic RXD usage being higher in the non-obese group. This was surprising given the reproductive issues and the increase in depression and other mental health disorders associated with obesity. ${ }^{33}$ The former could be explained because there is a significant association between high TSH and high BMI and low free-T4 and high BMI. These levels may not be outside of the "normal" range for these values but still cause an increase in BMI which could mean that RXD use would not necessarily be indicated. ${ }^{34}$ The latter could be explained by unrecognized or undiagnosed mental health issues in individuals with obesity that are solved by increasing food intake, mostly in the form of carbohydrates and fats. ${ }^{35}$ 
medRxiv preprint doi: https://doi.org/10.1101/2021.11.18.21266536; this version posted November 19, 2021. The copyright holder for this preprint (which was not certified by peer review) is the author/funder, who has granted medRxiv a license to display the preprint in perpetuity. It is made available under a CC-BY-NC-ND 4.0 International license.

In looking at tracking the use of specific RXD prescribed for weight loss, there was a small proportion of the population that utilized these drugs. The problem with further study of these RXD is that many of them were approved outside of the 12-year survey data used in this project. Additionally, many of the drugs used for weight loss are also used for other purposes such as management of diabetes or as a general CNS stimulant. Based on the information available it was unclear why respondents used a specific RXD. This made it difficult to understand and analyze the use of these drugs. 
medRxiv preprint doi: https://doi.org/10.1101/2021.11.18.21266536; this version posted November 19, 2021. The copyright holder for this preprint (which was not certified by peer review) is the author/funder, who has granted medRxiv a license to display the preprint in perpetuity.

It is made available under a CC-BY-NC-ND 4.0 International license .

When looking at both DS use and RXD use, the population with obesity was more likely to use RXD but less likely to use DS compared with the non-obesity population. It is consistent with a previous report that only $33.9 \%$ adults use DS for weight loss. ${ }^{36}$ Similar results were also obtained regarding sex, age, and financial status. ${ }^{37}$ Physical activity levels were found related with the likelihood of using DS, but we did not include them in this study. ${ }^{38}$ However, we found additional novel predictors, such as insurance status. This could be explained by the obese population feeling that either DS are not a necessary addition to their diet or that they are unaware of the potential benefits of certain DS in regard to the comorbid conditions associated with obesity. It may also indicate that the non-obese group makes better health decisions overall that include taking DS.

The experiments with machine learning models showed that predictions of RXD and DS use could be improved. It would be interesting to find alternative variables that may better predict RXD and DS use. For example, diagnostic information, out-of-pocket costs, and RXD coverage information. Being able to predict this information could again inform patient education. If it is known that certain variables can be used, then patients can know their possibility of needing RXD or being educated about DS use specific to their situation.

Overall, these findings indicate that there is a correlation between obesity status and RXD and DS use. Since it appears that the more used RXD types are associated with the comorbid conditions related to obesity instead of treating obesity directly, there may be opportunities for better health education. This would include education on the lifestyle changes to minimize both obesity in general but also to minimize the impact of these comorbid conditions. There is also a lower use of DS in the obese population. This also offers an opportunity for patient education in terms of DS like omega-3 fatty acids and Vitamin B/B-Complex which are shown to impact 
medRxiv preprint doi: https://doi.org/10.1101/2021.11.18.21266536; this version posted November 19, 2021. The copyright holder for this preprint (which was not certified by peer review) is the author/funder, who has granted medRxiv a license to display the preprint in perpetuity.

It is made available under a CC-BY-NC-ND 4.0 International license .

cardiovascular health, omega-3 fatty acids which are shown to impact weight loss and to maintain blood sugar, and multivitamin/multiminerals which are shown to impact general overall health. ${ }^{39}$ NHANES does not have information specifically geared towards delineating what may be considered a DS whose main purpose is weight loss. Efficacy for these has not been confirmed but some have shown a correlation with negative health effects, meaning that the risks could outweigh the benefits. ${ }^{40}$ These types of DS should also be part of the patient education conversation.

Based on Figures 1 and 2(a), there seems to be a point in the 20-30 age range that would be ideal for addressing obesity proactively and aggressively before it escalates into having comorbidities that require RXD. Additionally, there is an opportunity for better education in those under 20 as studies show that obesity in childhood and adolescence can lead to obesity as an adult. ${ }^{41}$ With obesity in childhood comes the associated comorbidities seen in individuals with obesity in adulthood that require RXD. Education has shifted from education on treating obesity to education on prevention of obesity as losing small amounts of weight or maintaining a healthy weight are more effective then treating obesity once it has developed. ${ }^{42}$ Obesity education may need to adapt from strict diet recommendations that do not tend to have lasting impacts. One problem is that it is still not clear what the impact of various education approaches, throughout different age groups, are on actual decreases in BMI, especially when compared with more systematic societal changes. Moreover, access to healthcare, which can be influenced by a variety of factors, can also impact access to obesity education.

\section{Limitations}

In most of the survey cycles used, there was no reason or diagnosis code associated with the report of RXD use. This means that we do not know why a respondent was taking a certain 
medRxiv preprint doi: https://doi.org/10.1101/2021.11.18.21266536; this version posted November 19, 2021. The copyright holder for this preprint (which was not certified by peer review) is the author/funder, who has granted medRxiv a license to display the preprint in perpetuity.

It is made available under a CC-BY-NC-ND 4.0 International license .

RXD. In addition, only primary category was used to type the various RXD. This means that if an RXD has multiple uses or off-label uses that cross-disease categories, it would not be evident in these results. Another limitation is that NHANES is a cross-section survey. It is thus not possible to infer any casual relationships between the variables.

\section{Future Work}

The most recent release of NHANES survey cycle (2017-2018) does include a diagnosis code with the RXD information. A future project that contains richer data in regard to RXD and DS use would provide more insight. Even though national health surveys like NHANES provide enormous opportunities for answering many important health-related questions, they have not been used widely for patient education and informatics research except for a few studies of our own. ${ }^{43-45}$ In future work, we also plan to build informatics tools such as a data dashboard to visualize various types of analyses of the NHANES data to provide patients, policy makers, and health providers a way to explore the RXD and DS use in the general population and certain population subgroups.

\section{Conclusions}

As obesity becomes a larger issue and the weight crisis in the United States becomes increasingly detrimental more needs to be done to understand the overall health status associated with this population and how to educate about the obesity, the comorbidities, and preventive measures that may help. Knowing how RXD use and DS use are different from those without obesity is only the start. Further steps can be taken to understand why there are differences and how the underlying diseases and conditions can be pre-empted in this group. Further knowledge on the association between obesity, DS, and RXD can inform patient education with the help of informatics tools such as data dashboards. Having individuals that truly understand the causes of 
medRxiv preprint doi: https://doi.org/10.1101/2021.11.18.21266536; this version posted November 19, 2021. The copyright holder for this preprint (which was not certified by peer review) is the author/funder, who has granted medRxiv a license to display the preprint in perpetuity.

It is made available under a CC-BY-NC-ND 4.0 International license .

and lifestyle changes needed to change obesity status should improve overall health in the United

States.

\section{Acknowledgments}

This study was supported in part by the National Institute on Aging (NIA) of the National Institutes of Health (NIH) under Award Number R21AG061431; and the University of Florida Clinical and Translational Science Institute, which is supported in part by the NIH National Center for Advancing Translational Sciences under award number UL1TR001427; and National Center for Complementary and Integrative Medicine (NCCIH) of NIH under Award Number R01AT009457. The content is solely the responsibility of the authors and does not necessarily represent the official views of the NIH.

\section{Competing Interests}

None

\section{References}

1. Ruban A, Stoenchev K, Ashrafian H, Teare J. Current treatments for obesity. Clin Med (Lond). 2019 May;19(3):205-12.

2. Yanovski SZ, Yanovski JA. Progress in Pharmacotherapy for Obesity. JAMA. 2021 Jul 13;326(2):129-30.

3. Gadde KM, Martin CK, Berthoud H-R, Heymsfield SB. Obesity: pathophysiology and management. J Am Coll Cardiol. 2018 Jan 2;71(1):69-84.

4. Yanovski SZ, Yanovski JA. Long-term drug treatment for obesity: a systematic and clinical review. JAMA. 2014 Jan 1;311(1):74-86.

5. Li R, Serdula MK, Williamson DF, Bowman BA, Graham DJ, Green L. Dose-effect of fenfluramine use on the severity of valvular heart disease among fen-phen patients with valvulopathy. Int J Obes Relat Metab Disord. 1999 Sep;23(9):926-8.

6. Li M-F, Cheung BM. Rise and fall of anti-obesity drugs. World J Diabetes. 2011 Feb $15 ; 2(2): 19-23$. 
medRxiv preprint doi: https://doi.org/10.1101/2021.11.18.21266536; this version posted November 19, 2021. The copyright holder for this preprint (which was not certified by peer review) is the author/funder, who has granted medRxiv a license to display the preprint in perpetuity.

It is made available under a CC-BY-NC-ND 4.0 International license .

7. Sharretts J, Galescu O, Gomatam S, Andraca-Carrera E, Hampp C, Yanoff L. Cancer risk associated with lorcaserin - the FDA's review of the Camellia-Timi 61 trial. N Engl J Med. 2020 Sep 10;383(11):1000-2.

8. Gahche JJ, Bailey RL, Potischman N, Ershow AG, Herrick KA, Ahluwalia N, et al. Federal monitoring of dietary supplement use in the resident, civilian, noninstitutionalized US population, National Health and Nutrition Examination Survey. J Nutr. 2018 Aug;148(Suppl 2):1436S-1444S.

9. Kantor ED, Rehm CD, Haas JS, Chan AT, Giovannucci EL. Trends in prescription drug use among adults in the United States from 1999-2012. JAMA. 2015 Nov 3;314(17):1818-31.

10. Hruby A, Hu FB. The epidemiology of obesity: a big picture. Pharmacoeconomics. 2015 Jul;33(7):673-89.

11. Randhawa AK, Parikh JS, Kuk JL. Trends in medication use by body mass index and age between 1988 and 2012 in the United States. PLoS One. 2017 Sep 20;12(9).

12. Stokes A, Lundberg DJ, Hempstead K, Berry KM, Baker JF, Preston SH. Obesity and incident prescription opioid use in the u.s., 2000-2015. Am J Prev Med. 2020 Jun;58(6):766-75.

13. Khalil H, Ellwood L, Lord H, Fernandez R. Pharmacological treatment for obesity in adults: an umbrella review. Ann Pharmacother. 2020 Jul;54(7):691-705.

14. Singh AK, Singh R. Pharmacotherapy in obesity: a systematic review and meta-analysis of randomized controlled trials of anti-obesity drugs. Expert Rev Clin Pharmacol. 2020 Jan;13(1):53-64.

15. Squadrito F, Rottura M, Irrera N, Minutoli L, Bitto A, Barbieri MA, et al. Anti-obesity drug therapy in clinical practice: Evidence of a poor prescriptive attitude. Biomed Pharmacother. 2020 Aug;128.

16. Srivastava SB. Is there a prescription to treat pediatric obesity? Am J Lifestyle Med. 2020 Feb;14(1):36-9.

17. Uche UI, Suzuki S, Fulda KG, Zhou Z. Environment-wide association study on childhood obesity in the U.S. Environ Res. 2020 Dec;191.

18. Doerrmann C, Oancea SC, Selya A. The association between hours spent at work and obesity status: results from NHANES 2015 to 2016. Am J Health Promot. 2020 May;34(4):359-65.

19. Liao S, Wu N, Gong D, Tang X, Yin T, Zhang H, et al. Association of aldehydes exposure with obesity in adults. Ecotoxicol Environ Saf. 2020 Sep 15;201. 
20. Wu B, Jiang Y, Jin X, He L. Using three statistical methods to analyze the association between exposure to 9 compounds and obesity in children and adolescents: NHANES 2005-2010. Environ Health. 2020 Aug 31;19(1):94.

21. Zhang Y, Dong T, Hu W, Wang X, Xu B, Lin Z, et al. Association between exposure to a mixture of phenols, pesticides, and phthalates and obesity: Comparison of three statistical models. Environ Int. 2019 Feb;123:325-36.

22. Palmer MK, Toth PP. Trends in lipids, obesity, metabolic syndrome, and diabetes mellitus in the united states: an NHANES analysis (2003-2004 to 2013-2014). Obesity (Silver Spring). 2019 Feb;27(2):309-14.

23. Kim D, Hou W, Wang F, Arcan C. Factors affecting obesity and waist circumference among us adults. Prev Chronic Dis. 2019 Jan 3;16.

24. Hodish I. Insulin therapy, weight gain and prognosis. Diabetes, Obesity and Metabolism. 2018 Sep 1;20(9):2085-92.

25. NHANES Survey Methods and Analytic Guidelines [Internet]. [cited 2021 Mar 9]. Available from: https://wwwn.cdc.gov/nchs/nhanes/analyticguidelines.aspx

26. Gelfand A, Tangney CC. Analyses and interpretation of cannabis use among NHANES adults. European Journal of Preventive Cardiology. 2018 Jan 1;25(1):40-1.

27. Frank E, Hall M, Trigg L, Holmes G, Witten IH. Data mining in bioinformatics using Weka. Bioinformatics. 2004 Oct 12;20(15):2479-81.

28. Stessman J, Jacobs JM, Ein-Mor E, Bursztyn M. Normal body mass index rather than obesity predicts greater mortality in elderly people: the Jerusalem longitudinal study. Journal of the American Geriatrics Society. 2009;57(12):2232-8.

29. Ashman JJ, Hing E, Talwalkar A. Variation in physician office visit rates by patient characteristics and state, 2012. NCHS Data Brief. 2015 Sep;(212):1-8.

30. Martin CB, Hales CM, Gu Q, Ogden CL. Prescription drug use in the United States, 20152016 [Internet]. 2019 May [cited 2021 Aug 2]. Report No.: 334. Available from: http://www.cdc.gov/nchs/products/databriefs/db334.htm

31. Kirby JB, Taliaferro G, Zuvekas SH. Explaining racial and ethnic disparities in health care. Med Care. 2006 May;44(5 Suppl):I64-72.

32. Gu Q, Dillon CF, Burt VL. Prescription drug use continues to increase: U.S. prescription drug data for 2007-2008. National Center for Health Statistics, Centers for Disease Control and Prevention, U.S. Department of Health and Human Services; 2010 Sep p. 8. Report No.: 42. 
33. de Wit L, Luppino F, van Straten A, Penninx B, Zitman F, Cuijpers P. Depression and obesity: a meta-analysis of community-based studies. Psychiatry Res. $2010 \mathrm{Jul}$ $30 ; 178(2): 230-5$.

34. Knudsen N, Laurberg P, Rasmussen LB, Bülow I, Perrild H, Ovesen L, et al. Small differences in thyroid function may be important for body mass index and the occurrence of obesity in the population. J Clin Endocrinol Metab. 2005 Jul;90(7):4019-24.

35. Wurtman RJ, Wurtman JJ. Brain serotonin, carbohydrate-craving, obesity and depression. Obesity Research. 1995;3(S4):477S-480S.

36. Pillitteri JL, Shiffman S, Rohay JM, Harkins AM, Burton SL, Wadden TA. Use of dietary supplements for weight loss in the United States: Results of a national survey. Obesity. 2008;16(4):790-6.

37. Lubowiecki-Vikuk A, Król-Zielińska M, Kantanista A. Consumption of dietary supplements to support weight reduction in adults according to sociodemographic background, body mass index, waist-hip ratio, body fat and physical activity. Journal of Health, Population and Nutrition. 2019 Nov 5;38(1):31.

38. Kofoed CLF, Christensen J, Dragsted LO, Tjønneland A, Roswall N. Determinants of dietary supplement use - healthy individuals use dietary supplements. British Journal of Nutrition. 2015 Jun;113(12):1993-2000.

39. He Z, Barrett LA, Rizvi R, Tang X, Payrovnaziri SN, Zhang R. Assessing the use and perception of dietary supplements among obese patients with National Health and Nutrition Examination Survey. AMIA Jt Summits Transl Sci Proc. 2020 May 30;2020:231-40.

40. Office of Dietary Supplements - dietary supplements for weight loss [Internet]. [cited 2021 Aug 2]. Available from: https://ods.od.nih.gov/factsheets/WeightLoss-HealthProfessional/

41. Simmonds M, Burch J, Llewellyn A, Griffiths C, Yang H, Owen C, et al. The use of measures of obesity in childhood for predicting obesity and the development of obesityrelated diseases in adulthood: a systematic review and meta-analysis. Health Technol Assess. 2015 Jun;19(43):1-336.

42. Gill T, King L, Caterson I. Obesity prevention: necessary and possible. A structured approach for effective planning. Proc Nutr Soc. 2005 May;64(2):255-61.

43. He Z, Wang S, Borhanian E, Weng C. Assessing the collective population representativeness of related type 2 diabetes trials by combining public data from clinicaltrials.gov and NHANES. Stud Health Technol Inform. 2015;216:569-73.

44. He Z, Ryan P, Hoxha J, Wang S, Carini S, Sim I, et al. Multivariate analysis of the population representativeness of related clinical studies. J Biomed Inform. 2016 Apr;60:6676. 
medRxiv preprint doi: https://doi.org/10.1101/2021.11.18.21266536; this version posted November 19, 2021. The copyright holder for this preprint (which was not certified by peer review) is the author/funder, who has granted medRxiv a license to display the preprint in perpetuity.

It is made available under a CC-BY-NC-ND 4.0 International license .

45. He Z, Charness N, Bian J, Hogan WR. Assessing the comorbidity gap between clinical studies and prevalence in elderly patient populations. IEEE EMBS Int Conf Biomed Health Inform. 2016 Feb;2016:136-9. 


\section{$35.00 \%$}

$30.00 \%$

$25.00 \%$

$20.00 \%$

$15.00 \%$

$10.00 \%$

$5.00 \%$

$0.00 \%$

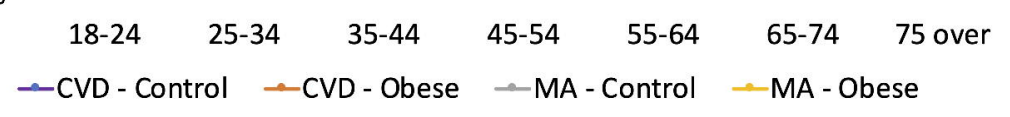




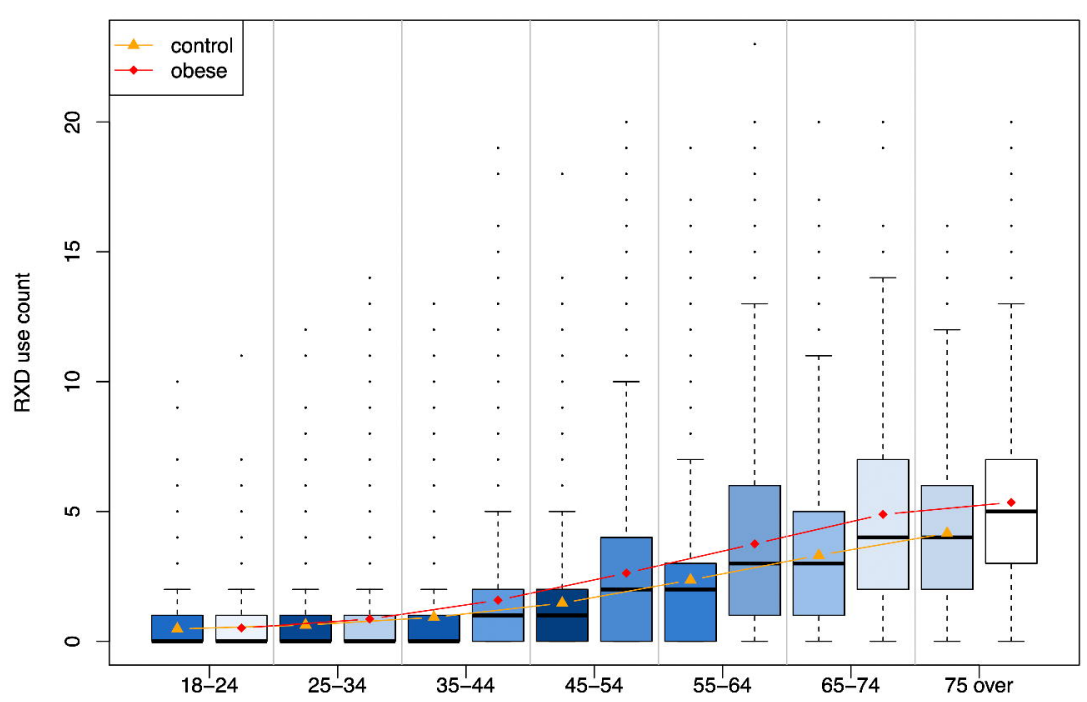

(a)

Age group

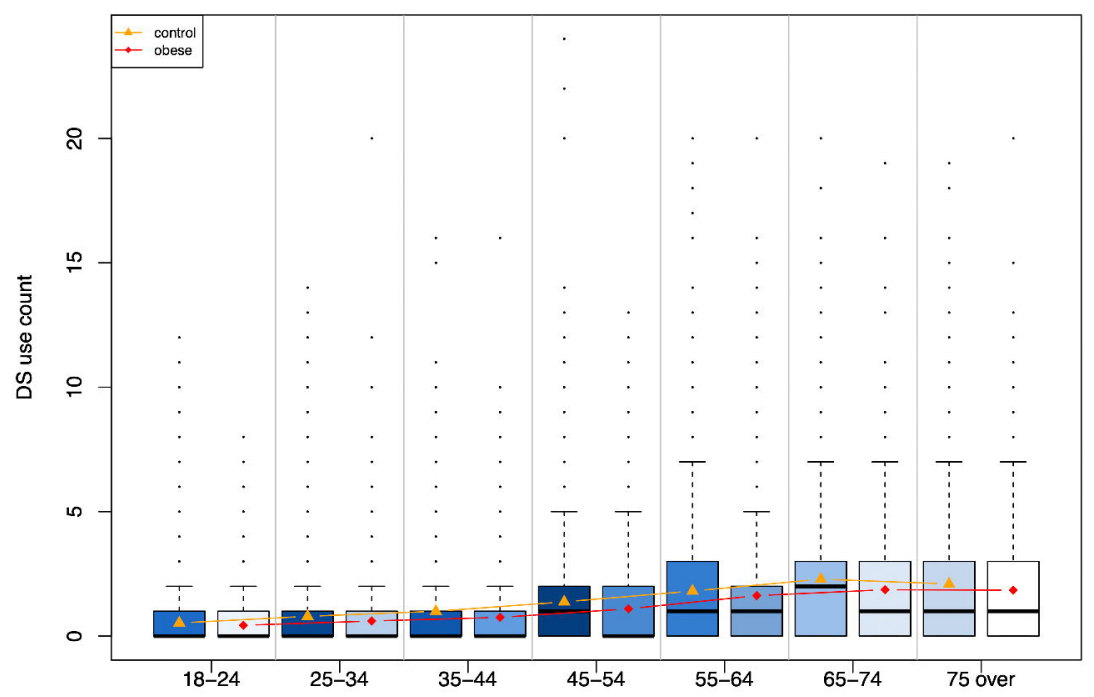

(b)

Age group

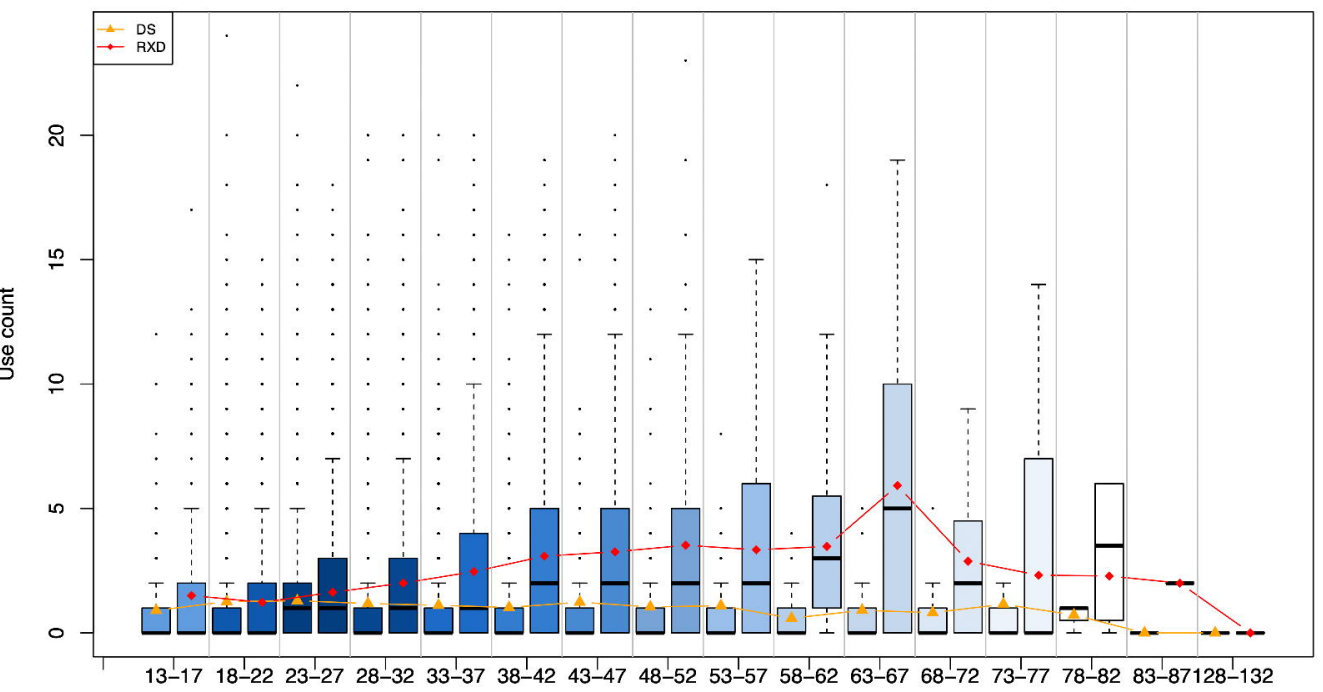

(c)

BMI 